\title{
Human Resource Management in State and Local Government in the United States: Avoiding Liability for Discrimination under Title 42 U.S.C. $§ 1983$
}

\author{
John A. Sample \\ Askew School of Public Administration and Policy \\ Florida State University, United States \\ E-mail: jsample@fsu.edu
}

Received: June 21, 2017 Accepted: July 12, 2017 Online published: July 30, 2017

doi:10.5296/ijhrs.v7i3.11427 URL: https://doi.org/10.5296/ijhrs.v7i3.11427

\begin{abstract}
The purpose of this review is to summarize Title 42 U.S.C. $§ 1983$, sometimes known as the "other" or "original" federal discrimination law in the United States that applies to elected officials, their appointed public administrators, and other employees in state and local governments. This federal statute provides a procedural process that allows a person to bring a private right of action to seek redress when just laws and policies are administered unjustly by state and local governmental entities. A hypothetical set of facts from a municipal setting is used to explore a typical Title 42 U.S.C. $§ 1983$ proceeding. Included in the review are typical defenses and immunities that make these proceedings for both the complaining party and the political entity complex, if not paradoxical. Strategies to prevent such claims are also discussed.
\end{abstract}

Keywords: Title 42 U.S.C. $§ 1983$, state and local government, employment discrimination, defenses and immunities.

\section{Introduction and Purpose}

State and local governments in the United States are continuously under threat of civil litigation. Given our litigious society, these political entities are assumed by the electorate and others to have "deep pockets" that provide for legal remedies, such as damages for complaints proven in a court of law against a municipality or as a negotiated settlement between the governmental entity and the individual making a complaint. Legal claims against public organizations run the gamut from opportunistic to legitimate civil claims by their employees, the citizenry, and other organizations (Jarrett, 2008; Leazes, 1995; Walter, 1992). 
The United States Constitution, federal and state laws are designed to protect the civil rights of all persons in their respective jurisdictions. Yet the question arises, under what circumstances may a governmental entity intervene when another governmental entity fails to follow its own lawful statutes, ordinances and policies over its citizens?

The purpose of this review is to summarize Title 42 U.S.C. $\$ 1983$ that applies to elected officials, their appointed public administrators, and other employees in state and local governments. While existing state laws protected all citizens in theory, its protection in practice was unavailable to most freed slaves in the south since those charged with enforcing those laws were unable or unwilling to do so. This federal statute provides a procedural process that allows a person to bring a private right of action to seek redress when just laws and policies are administered unjustly by state and local governments.

A hypothetical set of facts from a municipal setting is used to explore a typical Title 42 U.S.C. $\S 1983$ proceeding. Included in the review are typical defenses and immunities that make these proceedings for both the complaining party and the political entity complex, if not paradoxical (Blum, 2015; Berman, Bowman, West, and Van Wart, 2016). Strategies to prevent such claims are also reviewed.

\section{Historical Background}

The end of slavery after the Civil War required the United States Congress to ensure that the civil rights of all freed men and women were followed in the various states. Under reconstruction, state, county and local officials in the south were not extending to these citizens equal rights under existing state and federal laws. There were widespread deprivations of civil rights and the unwillingness or inability of authorities in those states to protect those rights or punish wrongdoers. Former slaves were denied the right to make contracts and to buy and sell property, both of which are necessary for commerce to develop equally among all citizens (Zinn, 1999).

Congress enacted the Civil Rights Act of $1871 \S 1983$ in response to the widespread deprivations of civil rights in the southern states and the inability or unwillingness of authorities in those states to protect those rights or punish wrongdoers (Blum, Koeleveld, Rudin, and Schwartz, 2016). This Act, also known as the Ku Klux Klan Act, was passed by Congress after the Civil War to reinforce the constitutional right of all freedmen to "have the same right, in every State and Territory in the United States, to make and enforce contracts, to sue, be parties, and give evidence, inherit, purchase, lease, sell, hold, and convey real and personal property, and to full and equal benefit of all laws and proceedings for the security of person and property, as is enjoyed by white citizens. ..”.

State and local law enforcement and corrections agencies are often targeted for this type of litigation (Ross, 2012; Hansen and Daley, 1994). Examples in the municipal police and sheriffs' offices include excessive use of force, pursuit and vehicle operation, first-responder, and violations of civil rights (French, 2009; Kernodle, 2001). According to Ross (2000), over 1,500 Title 42 U.S.C. $§ 1983$ civil rights cases have been litigated against local law enforcement agencies between the years 1989 to 1999, with the agency prevailing about half 
the time. In Cooper v. Pate (1964), the United States Supreme Court held that state prisoners could bring lawsuits against correctional officers under Title $42 \S 1983$. Since the Pate decision in 1964, prisoner litigation has flooded state and federal courts by 200 percent. Since $1980, \S 1983$ civil actions have become the method most often used by state prisoners and jail detainees filing legal actions against correctional officers" (Ross, 2012).

Analogous litigation in other governmental sectors include handling and disposal of toxic waste, proper care of children in foster care and public schools, residential treatment for the mentally and emotionally disturbed, emergency room practices in public hospitals, stringing high-voltage by a public utility, and unsafe operation of machinery, such as fork lifts in a municipal warehouse (Steinglass, 1988). Municipalities are well advised to have a formal risk management system that covers a multitude of potential litigation that could result in a $\S$ 1983 proceeding (Corcoran, 2015)

\section{Angela's Termination}

The following hypothetical case facts provide a background for understanding how a Title 42 USC § 1983 proceeding applies to a variety of legal questions under the United States Constitution and several federal statutes.

Angela is a 41-year-old African-American woman who has been confined to a wheelchair due to a tragic automobile accident at the age of 23. She converted to Islam shortly after her accident and has been active in her faith ever since. Angela was a public relations specialist for a medium sized city until her termination eight months ago by the city council. She had been with the city for the last nine years, and by all accounts was an outstanding advocate of the city's mission and principles of governance to the public and media outlets.

Angela was hired by the city manager and her direct supervisor, both of whom were women. The city manager resigned her position for a promotion to another city. The new city manager, hired by the city council, is a young, brash, white male from a small town. Within days of his arrival, the new city manager told Angela that he was concerned that she did not present the proper "image" to promote the "untapped business" for commercial opportunities for the city. He placed her on a 30-day probation, at which time he would decide whether to recommend to the city council that she be fired.

Angela is understandably upset by this turn of events. She went online to research the background of the new city manager. She discovered that he had been fired from his previous position as city manager for making racially insensitive remarks. Angela was concerned not only about her job but also about the welfare of the city she loved. She presented her findings about the new city manager to the city council publicly during a regularly scheduled monthly meeting. The city council, nonplussed by Angela's findings, passed a resolution declaring its unqualified support for the new city manager.

At the end of her 30-day probationary period, the new city manager informed her that he would recommend to the city council that she be terminated. Under the city's charter, Angela could only be terminated by the city council, and thus the new city manager could only recommend that she be terminated. At the next meeting, the five-member city council, 
including the mayor, discussed the city manager's recommendation that she be terminated. At the next meeting, the five-member city council, including its mayor, discussed the new city manager's recommendation and unanimously voted to terminate her employment.

Eight months have passed since her termination from the city. She has been actively searching for a job, but has not been able to find any work. She has also been extremely upset about what happened to her. She did not seek legal advice and file any complaints under existing federal and state civil rights statutes. Her opportunity has passed for filing a complaint within 180 days alleging discrimination under the Civil Rights Act of 1964.

Now, Angela is seeking advice from a legal aid attorney regarding her rights under the Patient Protection and Affordable Care Act. Her attorney, hearing the complete story from Angela regarding her termination by the city council, believes that there is another legal remedy that is available for her to pursue. The attorney recalls from her studies in law school that several civil rights statutes were passed after the Civil War. A quick search reveals the following language from the Civil Rights Act of 1871, Title 42, U.S.C. $§ 1983 .{ }^{1}$

Every person who, under color of any statute, ordinance, regulation, custom, or usage, of any State or Territory or the District of Columbia, subjects, or causes to be subjected, any citizen of the United States or other person within the jurisdiction thereof to the deprivation of any rights, privileges, or immunities secured by the Constitution and laws, shall be liable to the party injured in an action at law, suit in equity, or other proper proceeding for redress ...

\section{Overview of Title 42 U.S.C. $§ 1983$}

A claim brought pursuant to $\S 1983$ "is not itself a source of substantive right, but merely provides a method for vindicating federal rights elsewhere conferred" (Graham v. Connor, 490 U.S. 386 (1989), at 394)). This legal procedure is simply the vehicle to bring the deprivation of a civil right based upon some underlying substantive law, usually the Constitution of the United States, such as the First or Fourteenth Amendment, as is the case with our hypothetical Angela. Congress did not establish federal courts as the exclusive forum to remedy these deprivations of civil rights. This proceeding may be brought in either state or federal court (Steinglass, 1988).

The requirement that a defendant act under color of law is treated as the equivalent to "the state action" requirement under the Fourteenth Amendment. The "under-color-of-state" element of a $\S 1983$ proceeding means government action, and thus excludes private conduct, no matter how discriminatory or wrongful. The state action requirement reflects judicial recognition that most rights secured by the Constitution are protected only against infringement by governments. A private organization, association, or individual may at times be treated as if the deprivation of a civil right was caused by a governmental entity (Swanberg, 1991). Specifically, a state action may be found if, there is such a close connection between the state and the prohibited action by the state that what appears to be private behavior may be fairly treated as that of the state itself (Collins, 2011). 
In the hypothetical case alleged above for Angela, her $\S 1983$ claim arises primarily from the First or Fourteenth amendment of the Constitution of the United States. There is no dispute that the decision to terminate the employment of Angela was under "color of state law." Her termination was recommended by the city manager and acted upon by the city council.

"Person in his or her individual capacity"

The law is well established that states are not "persons" within the meaning of this type of proceeding, meaning that a state and its agencies may not be sued for monetary damages (Steinglass, 1988). Although a state or municipality cannot be sued for monetary damages under $\S 1983$, a state employee can still be sued in his or her individual capacity.

Given $\S 1983$, a "person" is an individual and includes a government employee or official acting under color of state law who can be sued in his or her individual capacity. The individual, not the governmental entity, would be responsible for any judgement involving monetary damages (Lee, 1987). Note that some local governments may elect to have insurance which covers the employer and its employees in the event of this type of litigation (Sample, 2007b).

Given the facts in Angela's hypothetical case, her attorney will be careful to state in civil court filing papers and throughout the complaint that she is suing the "person" in his or her "individual capacity." Otherwise the court might construe the lawsuit as one against an individual in his or her official capacity. A suit against a government employee, such as members of the city council or the city manager in their official capacity is the same as a suit against the governmental entity itself (Steinglass, 1988).

The only government employees who are not subject to suit under $\S 1983$ are federal employees. It should be noted that federal employees may be sued in their individual capacities in what is known as a Bivens action. In Bivens v. Six Unknown Named Agents of the Federal Bureau of Narcotics (403 U.S. 388 (1971)), the United States Supreme Court created a procedure similar to $\S 1983$ to authorize suits against federal employees in their individual capacities. The purpose of a Bivens suit is to deter federal officers from committing constitutional violations against citizens.

In addition to individuals being "persons" under $§ 1983$, local governments are also subject to liability for deprivation of civil rights. In the seminal case of Monell v. New York City Department of Social Service (436 U.S. 658 (1987)), the Supreme Court overruled its decision in Monroe v. Pape (365 U.S. 167 (1961)).

In Monroe v. Pape police officers conducted an unreasonable search and seizure of a residence. The complaint against the department and its thirteen officers occurred under "color of state law." This was the first case in which the Supreme Court allowed liability to attach to government officials who acted outside the scope of authority granted by state law. The Supreme Court held that the officers could be liable in their individual capacities, but that the City of Chicago as a municipality was shielded from liability under $\S 1983$. Only "persons" and not governmental entities under $\S 1983$ are subject to liability given the Court's ruling in Monroe v. Pape. 
In Monell v. New York City Department of Social Services, the United States Supreme Court held that the phrase "every person" as defined in $\S 1983$ includes municipalities and other governmental entities. Thus, not only state statutes, but also "policies and governmental customs" enacted or utilized by state and local governing entities, even though such custom had not received formal approval through the entity's decision making channels (Collins, 2011). Given this decision, it must be demonstrated that the governmental entity adopted or promulgated (however informal) a "custom" or policy that was the driving force behind the employees violation of constitutional rights of others. A pattern of constitutional violations and an awareness of them by high ranking officials must also be demonstrated (Walter, 1992).

A single hiring decision or instance of negligent training by a municipality is not sufficient to sustain a $\S 1983$ proceeding. Also note that the expected standard of proof requires a determination of deliberate indifference. Mere negligence or even gross negligence is not sufficient to establish liability. The complaining party must demonstrate that the municipality through its deliberate conduct was the "moving force" behind the injury in which there is the necessary degree of deliberate indifference along with a causal link between the municipal action and the deprivation of a federal right (Canton v. Harris, 1489 U.S. 378 (1989)).

A local governmental entity cannot be held liable solely because it employs a bad actor, a "tortfeasor" on a respondent superior theory. Instead, to hold a local government liable for a constitutional violation under $\S 1983$, the complaining party must show that the execution of a law, policy or custom of the local government caused the violation. Liability may be imposed for a single decision by policymakers under appropriate circumstances. To hold a local government liable for a single decision, the decision maker must possess final authority to establish policy with respect to the action ordered (Collins, 2011).

\subsection{Equal Protection Claims under Title VII}

Can a plaintiff, such as Angela in our hypothetical example, bring a claim pursuant to $\S 1983$ based upon the Equal Protection Clause of the Fourteenth Amendment because of her race (African-American) and gender (female), and the Free Exercise Clause of the First Amendment (religion)? The courts have generally held that Title VII does not preempt a $\S$ 1983 claim, leaving Angela the choice of bringing a claim under Title VII of the 1964 Civil Rights Act, or $\S 1983$ of 42 U.S.C., or both.

The question arises as to what must be proven in order for Angela to prevail given this panorama of potential cases of discrimination. A practical solution is that the courts may "apply the standards developed in Title VII litigation to similar litigation under $\S 1983$." In most Title VII cases, courts use the well settled burden shifting analysis first articulated by the U.S. Supreme Court in McDonnell Douglas Corp. v. Green (411 U.S. 792 (1973)). Under this analysis, to establish a prima facie case of discrimination for wrongful termination, as in Angela's hypothetical case, as the plaintiff, she must prove (1) that she is a member of a protected class, (2) she has satisfactorily performed her job, (3) her employment was terminated, and (4) she was replaced by someone of comparable qualifications outside the protected class. If the plaintiff establishes a prima facie case, the burden shifts to the employer to articulate a legitimate, non-discriminatory reason for the adverse employment 
action. If the employer produces a legitimate reason for the action, the burden shifts back to the plaintiff to demonstrate that the reasons given by the employer was a pretext for the adverse action (Landy, 2005).

From Angela's perspective as a plaintiff, there are several reasons for executing her privilege to file a discrimination lawsuit pursuant to $\S 1983$. First, the statute of limitations for a $\S 1983$ claim is three years. By contrast, an allegation of discrimination of the Civil Rights Act of 1964 must be filed with the Equal Employment Opportunity Commission within 180 days after the alleged prohibited employment practice occurred. Failure to comply with this requirement means that a lawsuit cannot be filed alleging violations of Title VII.

Given Angela's circumstances, her attorney should research the possibility that the Lilly Ledbetter Act of 2009 might apply to her case facts. Under this Act, an individual subjected to compensation discrimination under Title VII of the Civil Rights Act of 1964, the Age Discrimination in Employment Act of 1967, or the Americans with Disabilities Act of 1990 may file a charge within 180 (or 300) days.

A $§ 1983$ claim may be preferred over a Title VII claim in that only the employer can be sued in a Title VII action. As established earlier in this discussion, a government official or employee, acting under color of law, can be sued in his or her individual capacity. Also note that Title VII limits the amount of compensatory damages a plaintiff can recover, depending on the number of employees employed by the employer. By contrast, there are no such limitations on compensatory damages in a law suit filed under $\S 1983$ (Collins, 2011).

Thus, given Angela's hypothetical case example, although it is too late to file a claim pursuant to Title VII, she can file a $§ 1983$ claim based on the Equal Protection Clause of the Fourteenth Amendment and the Free Exercise Clause of the First Amendment for discrimination based on her race, gender and religion.

\subsection{Claims under Another Federal Statute}

Although most $\S 1983$ litigation is based upon rights secured by the United States Constitution, a claim may also be brought to vindicate a right established in a federal statute. Recall that the explicit language of $\S 1983$ states that a person can bring a claim for the "deprivation of any rights, privileges, or immunities secured by the Constitution and the laws." In order to sustain a $\S 1983$ proceeding, the complaining party must demonstrate that the federal statute creates an individually enforceable right. The Supreme Court held that this statute "means what it says," and thereby authorizes suits to enforce individual rights upon federal statutes as well as the U.S. Constitution (Steinglass, 1988).

For example, a $\S 1983$ claim based on age discrimination is preempted by the Age Discrimination in Employment Act (ADEA) of 1967. Congress intended that this act be a comprehensive and exclusive remedy for age discrimination. In Zombro v. Baltimore City Police Department (868 F.2d 1364 (4 ${ }^{\text {th }}$ Cir. (1989)), an appeals court affirmed that the ADEA is the exclusive remedy for age discrimination in the workplace.

A claim based on disability or handicap under the Americans with Disabilities Act (ADA) 
of 1990 preempts a $§ 1983$ proceeding. In Okwu v. McKim (682 F3d. 841 ( $9^{\text {th }}$ Cir. (2012)), the plaintiff suffered from psychiatric disorders that made her public employment unsuitable for the position of accounting officer for the State of California. She was placed on disability retirement pursuant to the state's retirement system. She exercised her right to seek reinstatement, which was not granted by the state's personnel system. The court of appeals held that $O k w u$ could not seek redress in a $\S 1983$ action as a substitute remedy given that Congress precluded such proceedings when it passed the ADA.

The Patient Protection and Affordable Care Act (ACA) (Public Law 111-14 (2010)) does not create a $\S 1983$ private right of action for enforcement of private health insurance reforms, but instead amends and incorporates existing federal statutes that include Employee Retirement Income Security Act (ERISA) and the Fair Labor Standards Act (FLSA). ERISA created a comprehensive law for the regulation of employee benefit plans. Private plaintiffs, either participants or beneficiaries, may bring actions against a plan to either recover benefits or to enforce or clarify the rights of the plaintiffs under the terms of the plan. The FLSA contains minimum wage provisions, child labor restrictions and a variety of other protections. Both the FLSA and ERISA may be used by private beneficiaries to enforce the ACA requirements if they believe that a company's restructuring to avoid the employer mandate penalty or other requirements has shortchanged their benefits or increased their workload without compensation (Collins, 2011).

Given the facts as presented by Angela in our hypothetical case, her attorney is obliged to inform Angela that certain federal statutes will preclude her from pursuing $§ 1983$ claims if those statutes provide specific relief for complainants.

\subsection{First Amendment Free Speech Claim}

The U.S. Supreme Court has made clear that public employees do not surrender all First Amendment rights by reason of their employment. Rather, the First Amendment protects a public employee's right, in certain circumstances, to speak as a citizen addressing matters of public concern.

In Pickering v. Board of Education (391 U.S. 563 (1968)), a school teacher wrote a letter to the editor of a local newspaper that criticized the school board's funding priorities. The teacher was subsequently terminated by the school board for disloyalty and insubordination. The United States Supreme Court reasoned that a public employee must satisfy a two-pronged test (i.e., the Pickering balancing test) in order to make a valid First Amendment claim pursuant to $\S 1983$. First, the public employee must have spoken as a citizen, not as an employee, on a matter of public concern. Second, the employee's interests in the expression at issue must have outweighed the employer's interest in providing effective and efficient services to the public. In order to make this determination, a court balances the government's interests in an effective and efficient workplace against the employee's free speech interests.

The issue before the United States Supreme Court in Garcetti v. Cebellos (2006) was whether the First Amendment protects a government employee from discipline based on speech made pursuant to the employee's official duties. The Court held that Cebellos, a public employee 
who made statements pursuant to his official duties "are not speaking as citizens for First Amendment purposes, and the Constitution does not insulate their communications from employer discipline" (Garcetti v. Cebellos, 126 S.Ct. 1951 (2006) at 1960)).

Given our hypothetical case involving Angela, in order to ensure that her statement is not made in regard to her "official duties" as q public employee, she, might be tempted to simply go to the media instead of raising the issue with her superior. However, it also appears that going to the media would cause more disruption in the workplace, thereby weakening the employer's legal argument with regard to the Pickering balancing test, even if the employee is fortunate enough to escape court's ruling in Cebellos. The practical result, of course, is that fewer government employees will step forward to report wrongdoing and corruption.

It can very well be argued that our hypothetical Angela did not make her statement to the city council pursuant to her official duties. She would have been speaking as a citizen on a matter of public concern in which the allegations about racial discrimination are matters of serious public concern. The city council would likely argue that as a public relations specialist, Angela's job was to speak for the city. Therefore, any public statements with regard to the city were made pursuant to her official duties, likely obviating her First Amendment protection.

\subsection{Procedural Due Process}

A public employee has both a procedural due process property and liberty interest under the Due Process Clause of the Fourteenth Amendment. "While a legislature can decide whether to grant property, the Constitution determines the degree of legal process and safeguards that must be provided before the government may take away that property" (Grundsman, 2015, p. ii).

The courts have repeatedly held that due process is necessary to determine if cause for adverse action, such as progressive discipline or termination, has been met. At a minimum, due process includes the right (1) to be notified of the government's intention to assert an adverse action against the employee and (2) a pre-determination hearing that provides a meaningful opportunity to respond before the action takes place (Cleveland Board of Education v. Loudermill, 841 Ed. 2d 494 (1985)); Reeves, 1989). Given the Loudermill case, this requirement applies to federal, state and local employees.

The essence of a liberty interest claim is that a public employee must be given notice and an opportunity to be heard when a government employer publicly disparages the employee's reputation or integrity. Such a claim would be brought as a $\S 1983$ proceeding pursuant to a four part test by a court. The employee would have to demonstrate the following: (1) The public employer states the existence of a serious character defect, such as dishonesty or immorality regarding the employee (2) that were made as part of a discharge or significant demotion or reassignment to a position outside the choice of the employee affecting the employees employment status (3) that included a public disclosure by the employer (4) in which the stigmatizing charges made by the employer are false (Collins, 2011; French, 2009).

Given our hypothetical case involving Angela and the city council discussion on whether to 
terminate her, she may have a procedural due process liberty interest, assuming that the council did not give her an opportunity to be heard. If she was not given a hearing either before or after she was terminated by the city council, she may also have a claim that the city violated her procedural due process property rights (Reeves, 1989).

Whether she has a possible claim depends on whether she had a "property interest" in her job. If she does, Angela can proceed with a lawsuit pursuant to $\S 1983$. She must initially demonstrate a "property" interest in continued employment in order to invoke a procedural due process protection. States and municipalities that follow an "at-will" employment doctrine means that both public and private employers may discharge an employee for any reason, including those which are arbitrary, irrational, or illogical without incurring liability, unless the employer violates a federal or state protected right (Landy, 2005; Cascio, 2015).

Unless a public employee has a contract for a specified time, or unless there is a state statute or local ordinance which provides a legitimate expectation of continued employment, such as a just cause provision for termination, the public employee, like counterparts in the private sector, is an at-will employee and does not have procedural due process rights. If a public employee does have a property interest in his or her job, then the local government must provide at least basic procedural due process, such as the right to confront and cross examine witnesses about material, disputed facts, and to have the case heard by an impartial and unbiased decision maker (Grundsman, 2015).

Given that the facts from our hypothetical case with the termination of Angela do not specify if she had an employment contract or whether her employment was subject to an enforceable "just cause" provision, further research would be necessary to determine whether she could bring a procedural due process property claim.

\section{Defenses to an Allegation Arising from a 42 U.S.C. $\$ 1983$ Claim}

State and local governments may have one or more "immunities" as a potential defense to a claim arising under $\S 1983$. The following three immunity defenses are the most common.

Legislative immunity shields elected officials from lawsuits filed against them in their individual capacities under certain circumstances. The pivotal factor is whether the elected officials were acting in a legislative or administrative, managerial, or ministerial capacity. Legislative immunity only attaches to legislative actions. Elected officials are absolutely immune when performing legislative acts; however, administrative actions are not protected (Collins, 2011).

Most budget decisions, by virtue of their impact on employment, either by creating or eliminating positions or by raising or lowering salaries, are generally decided by elected officials acting in a legislative capacity. Yet an elected official's employment and personnel decisions are generally administrative acts. The key question involves making a distinction between general and specific actions. For example, if the facts relate to specific individuals or situations and the decision impacts specific individuals or singles out particular individuals, the decision is deemed administrative. The action is legislative if the facts involve generalizations concerning a policy or state of affairs and the establishment of a general 
policy impacting a larger population (French, 2009).

Accordingly, when a local council eliminates an entire position, rather than merely terminating the employment of a specific individual, the council is regarded as having acted in a legislatively-protected manner. Conversely, when the city council terminates a specific individual but does not eliminate the position itself, the council is not acting in a legislative capacity, and is therefore not protected by legislative immunity (Groszyk and Madden, 1981).

The analysis as to whether the local governing body itself is subject to legislative immunity is a much simpler question to answer. For example, in Alexander v. Holden $\left(66 \mathrm{~F} .3 \mathrm{~d} 626\left(4^{\text {th }} \mathrm{Cir}\right.\right.$. (1995), at 68)) the court explicitly held that "The defense of legislative immunity by a county to a suit under $\S 1983$ is no longer a viable defense to alleged constitutional violations based on either the legislative or administrative actions of its legislature."

Given Angela's hypothetical example, the individual city council members would not be shielded by legislative immunity, since the council terminated a particular employee, rather than eliminating the position of public relations specialist. Also, the city council could not claim legislative immunity, regardless of whether its action was considered administrative or legislative in nature.

Under the doctrine of governmental immunity, a local government is immune from suit for the negligence of its employees in the exercise of governmental functions absent a waiver of immunity. In some jurisdictions, local governing bodies are entitled to governmental (or sovereign) immunity unless the governing entity, whether it be a city, county or school board, waives its immunity through the purchase of liability insurance, participation in a statutory risk pool, or otherwise consents to be sued (Groszyk and Madden, 1981).

It must be noted that governmental immunity does not apply to a claim brought pursuant to a $\S 1983$ proceeding. The U.S. Supreme Court has consistently held since the Monell decision that municipalities and other local governments do not enjoy immunity from suit, either absolute or qualified immunity under $\S 1983$. Simply stated, the doctrine of governmental (or sovereign) immunity does not apply to a local government or to its officials sued in their official capacities, since a suit against an official in his or her capacity is equivalent to a suit against the local government itself (French, 2009).

Although a state or local government cannot claim governmental immunity, government officials and employees sued in their individual capacities are entitled to assert the affirmative defense of qualified immunity (Groszyk and Madden, 1981). Qualified immunity shields government officials performing discretionary functions from individual liability for civil damages under $\S 1983$. Their conduct must not violate clearly established statutory or constitutional rights of which a reasonable person would have known (Collins, 2011). Government officials are entitled to the defense of qualified immunity unless a Title $42 \S$ 1983 claim satisfies the following two-prong test (the 'qualified immunity test'): (1) the allegations under the claim, if true, state a violation of a federal statutory or constitutional right; and (2) this violation was "insofar as their conduct does not violate clearly established statutory or constitutional rights of which a reasonable person would have known"). 
Given the facts in Angela's hypothetical scenario, the issue of qualified immunity will almost certainly be raised whenever a government official is sued in his or her individual capacity. At the time the city council fired Angela, the law was clearly established that it is unconstitutional, or at least unlawful, to fire someone because of their race, gender, religion, age and handicap. In this instance, it is very doubtful that qualified immunity would be a valid defense; however, there may be a genuine issue of fact as to whether the council members are entitled to qualified immunity based on Angela's First Amendment claim.

\section{Collecting Damages}

The Unites States Supreme Court has consistently held that tort-like damages are available in a $\S 1983$ proceeding. The level of damages is ordinarily determined according to the principles common law of torts (Collins, 2011). A plaintiff in this proceeding may recover damages that naturally flow from the deprivation of rights from the constitutional violation, including not only out-of-pocket loss and other monetary harms, but also injuries such as impairment of reputation, personal humiliation, mental anguish and suffering. Stated differently, the plaintiff cannot argue to a jury for damages in the amount of $\$ 100,000$ just because the government violated his or her constitutional rights. The plaintiff must prove damages, just as would be the case in a personal injury suit. If there are no actual damages which naturally flow from the deprivation of a constitutional right, a jury would be instructed to only award nominal damages to the plaintiff.

A jury may award punitive damages against an individual defendant sued in his or her individual capacity, however such damages are not available against a governmental entity (French, 2009)). Also, a plaintiff may recover attorney costs and fees if he or she prevails in a $\S 1983$ proceeding. It is important to note that attorney fees may eclipse any damages awarded to a plaintiff. For example, a plaintiff may be awarded nominal damages, as little as one dollar, yet the attorney's fees may be substantially higher (Collins, 2011).

Given the hypothetical facts based on Angela assertions, she can bring a $\S 1983$ proceeding against the city, since it was an official policy (a decision by the city council) which resulted in her termination. She may also have similar claims against the city manager and the five city council members in their individual capacities.

\section{Strategies for Preventing Title 42 U.S.C. $\$ 183$ Claims}

State and local governments have a responsibility to its citizens, residents and taxpayers to actively prevent and reduce the potential for all litigation, including $\S 1983$ proceedings. Explaining litigation costs to the citizens as a "necessary cost of doing the city's business" lulls public officials into a mindset of "business as usual." The following recommendations will require effort and cost, yet are designed to prevent or reduce the costs associated with settlements and judgements from the expense of defending a state or local government in legal proceedings.

\subsection{Conduct a Hazard Assessment and Analysis of Risk}

State and municipal governments are well advised to continually update and align risk 
management plans and operational policies based on information generated from a regularly scheduled risk analysis (Corcoran, 2015). This form of due diligence protects citizens and the organization if (and when) litigation occurs. Hazard assessment and the identification of high hazard tasks are both necessary, since one becomes an anchor for the other. Mapping of natural hazard areas places a municipality on notice regarding any actions which may cause or "worsen hazards, such as building and operating a landfill in an area with high ground water or construction of a dike in a floodway" (Kusler, 1985, at 121). Either of these two options may place members of legally protected categories of residents in harm's way. For example, Hurricane Katrina decimated the lowlands of New Orleans when dikes broke flooding the Ninth Ward. The poorest residents were vulnerable, race was deemed a factor in the slow response by all levels of government, and especially at risk were people with disabilities (Burns and Thomas, 2006). Update mitigation plans as information, technologies and strategies improve, including hazard preparedness plans, such as a hurricane or flooding evacuation plan.

Other aspects of state and local government operations may carry the potential for similar liability. High hazard tasks are also performed by other units in municipalities, such as public utilities, hospitals and schools for which similar analysis of risk is recommended. Human resources management professionals could use a similar process to create and analyze a database for complaints and litigation associated with state and federal laws regarding all forms of harassment, hostile environment, and discrimination (Berman, et al., 2016).

City and county law enforcement agencies are particularly vulnerable to $\S 1983$ proceedings (Ross, 2012). The following example describes one approach to identifying high hazard tasks. A police department begins by creating a database that associates specific incidents with job tasks and source data. Possible data sources include insurance payouts, workers' compensation claims, professional liability, and settlements and judgements against the police department that are associated with specific job tasks. Additional sources of information include the results of internal affairs investigations and citizen complaints that are also associated with specific job tasks. Once the database has been completed, request the assistance of "subject matter experts" (SME) to review the findings of the analysis of risk. Subject matter experts may represent the department's insurance underwriters, attorneys who specialize in tort and constitutional law claims, external consultants specializing in law enforcement, and human resource management specialists. The last step in the analysis of risk process is to have the SMEs rank order tasks in terms of high hazard tasks. The department uses this information to revise operational policies and procedures, update police academy and staff training programs and field training officer (FTO) programs for officers and their supervisors.

\subsection{Revise Risk Management Plans and Operational Policies}

Although municipal risk management systems have evolved significantly over the past four decades (Corcoran, 2015), some governmental entities, such as law enforcement, have failed to keep pace. Archbold (2005) conducted telephone interviews with 354 law enforcement agencies and concluded that only 14 agencies ( 0.039 percent) "identified risk management as 
one of several tools they use to control police-related liability (p. 30)." Especially vulnerable to $\S 1983$ proceedings are formal operational policies that have morphed into a "customary" way of doing business. For example, formal safety codes and practices for stringing high voltage power lines that creep into "customary" unsafe practices may result in death or serious injury due to deliberate indifference by supervisors (Steinglass, 1988).

\subsection{Update Job and Task Descriptions}

State and municipal governments are required under the Civil Rights Act of 1964 (14 Stat. 27-30, 1964)) to make all significant personnel decisions job related. The basis for such decisions is to complete a job analysis that specifies job tasks (Moody v. Albemarle Paper Company (422 US 405 ( 1975)); Griggs v. Duke Power Company (401 US 24 (1971)). The Americans with Disabilities Act of 1990 (104 Stat. 328 (1990)) requires employers to identify essential and non-essential tasks for purposes of determining reasonable accommodations for applicants and employees who have a physical or intellectual disability. An additional reason for updating job and task descriptions is to identify potential "high hazard" tasks that predict the potential for litigation against a state or local government (Ward, 1988; Sample, 1995).

\subsection{Educate, Train, and Document Results}

Position education and training regarding high hazard tasks as part of the agency's commitment for professionalizing the workforce, at all levels. By doing so, the agency sends a message that training is not just about complying with federal and state regulations or reducing the potential for litigation. A broader message is consistent with good citizenship that integrates the agency's mission into daily operations by its employees, including immunities.

Design, implement, and evaluate training systematically that fits the various contexts of the agency (Sample, 2007a). Elected officials, correctional officers, and policy analysts represent different contexts. Give serious consideration to the goals, scope, and approach to designing instruction. Goals focus the direction of the training effort, scope determines the breadth of the training effort, and approach represents the choice of delivery (Van Wart, Cayer, and Cook, 1993). Provide elected officials with a broad scope of instruction that includes not just state and local ethics laws and policies, but also a broader understanding of their responsibilities under the United States Constitution and applicable state and federal laws that bestow civil rights to people (Berman, et al., 2016).

Rely on qualified instructors with proven and current credentials. Retain copies of instructional objectives, course materials, instructor credentials, and program documentation. Do not get caught in an embarrassing situation where the instructor is called to testify about training program content, only to discover that his or her credentials were not current at the time of instruction. Consider having each participant sign a form at the end of the program certifying he or she (1) understands the content of the instruction, (2) agrees to abide by the policies set forth in the instruction, and (3) acknowledges receipt and acceptance of any relevant policies and procedures that are central to the instruction. This form of 
documentation should become part of an official's or administrator's personnel file. Note that some courts will rule that the absence of documentation is the equivalent of no training, even if such training was provided, yet not documented. Remember that all instructional content including notes kept by participants are subject to pretrial discovery in the event of a legal proceeding (Sample, 2007a).

\section{Conclusions}

Title 42 U.S.C. $\S 1983$ proceedings are designed to protect the civil rights of citizens against deliberate indifference by state and municipal officials who perform legislative and administrative functions. State laws and governmental policies that are selectively enforced without regard to citizens' civil rights may be litigated under Title $42 \S 1983$ in federal or state courts. This is an important reminder to elected officials and their public administrators to avoid opportunities for litigation with their names as defendants. State and local governments have an ethical responsibility to make sure their administrators perform their legally mandated responsibilities legally and ethically.

Local law enforcement and state and local correctional facilities are at the greatest risk for a $\S$ 1983 proceeding. Recent media attention regarding police shootings of minority suspects captured on social media should place elected and appointed officials on notice of the increasing possibility of litigation. Inadequate preparation of all higher-level officials and administrators in all facets of state and local government may result in costly settlements, court awarded damages, and negative media attention.

Notes

${ }^{1}$ Hereafter referenced as $\S 1983$ for the sake of brevity.

\section{References}

Archbold, C. A. (2005). Managing the bottom line: Risk management in policing. Policing: An International Journal of Police Strategies \& Management, 28(1), 30-48. https://doi.org/10.1108/13639510510580968

Berman, E. M., Bowman, J. S., West, J. P., \& Van Wart, M. R. (2016). Human resource management in public service. Los Angeles, CA: Sage.

Blum, K. M., Koeleveld, C., Rudin, J. B., \& Schwartz, M. (2016). Municipal liability of supervisors: Litigation significance of recent trends and developments. Touro Law Review, 29, 1, 93-117.

Burns, P., \& Thomas, M. O. (2006). The failure of the nonregime: How Katrina exposed ew Orleans as a regimeless City. Urban Affairs Review, 41, 4, 517-527. https://doi.org/10.1177/1078087405284888

Cascio, W. F. (2015). Managing human resources: Productivity, quality of work life, profits. New York: McGraw-Hill Education.

Collins, M. G. (2011). Section 1983 litigation in a nutshell ( $4^{\text {th }}$ Ed.). St. Paul, MN: West. 
Corcoran, S. (September 2015). The evolution of municipal risk management. Risk Management Magazine, 9 pages. Retrieved May 30, 2016 at https://www.google.com/webhp?sourceid=chrome-instant\&ion=1\&espv=2\&ie=UTF-8\#q=Th e+Evolution+of+Municipal+Risk+Management.

French, E. P. (2009). Employment laws and the public sector employer: Lessons to be Learned from a review of lawsuits filed against local governments. Public Administration Review, 69(1), 92-103. https://doi.org/10.1111/j.1540-6210.2008.01943.x

Groszyk, W. S., \& Madden, T. J. (1981). Managing without Immunity: The challenge for state and local government officials in the 1980s. Public Administration Review, 41(2), 268-278. https://doi.org/10.2307/3110084

Grundsman, S. T. (2015). What is due process in federal civil service employment? A report to the president and congress of the United States. Washington, DC: U.S. Merit Systems Protection Board.

Hanson, R.A., \& Daley, H. W. K. (1994). Challenging the conditions of prisons and jails. A report on section 1983 litigation. Washington, D.C: U.S. Department of Justice, Office of Justice Programs, Bureau of Justice Statistics. Retrieved from http:www.bjs.gov/content/pub/asci/CCOPAAJ.TXT.

Jarret, J. (2008). Personal liability and the public manager: Guarding against the lawsuit with your name on It. PM Public Management, 90(5), 22-24.

Kernoble, J. A. (2001). Policing the police: Clarifying the test for holding the government liable under 42 U.S.C. Vanderbilt Law Review, 54(1), 165-204.

Kusler, J. A. (1985). Liability as a dilemma for local managers. Public Administration Review, 90(5), 22-24. https://doi.org/10.2307/3135006

Landy, F. J. (2005). Employment discrimination litigation. San Francisco, CA: Jossey-Bass.

Leazes, F. J. (1995). Pay now or later: Training and torts in public sector human services. Public Personnel Management, 24(2), 167-181.

https://doi.org/10.1177/009102609502400206

Lee, Y. S. (1987). Civil liability and local governments: Myth and reality. Public Administration Review, 47(2), 160-171. https://doi.org/10.2307/975590

Reeves, T. Z. (1989). Due process before discipline: What public employers need to provide. Employee Responsibilities and Rights Journal, 2(3), 163-171. https://doi.org/10.1007/BF01423475

Ross, D. L. (2012). Civil liability in criminal justice (6 ${ }^{\text {th }}$ Ed.). London: Routledge.

Ross, D. L. (2000). Emerging trends in police failure to train liability. Policing: An international journal of police strategies and management, 23(2), 169-193. https://doi.org/10.1108/13639510010333796 


\section{Macrothink}

International Journal of Human Resource Studies

ISSN 2162-3058

2017, Vol. 7, No. 3

Sample, J. A. (2007a). Avoiding legal liability for adult educators, Human resource developers, and instructional designers. Malabar, FL: Krieger Publishing.

Sample, J. A. (2007b). The compelling argument for harassment prevention training: Implications for instructional designers. Performance and Improvement, 46(7), 18-26. https://doi.org/10.1002/pfi.145

Sample, J. A. (1995). Using subject matter experts to identify high liability tasks. Performance \& Instruction, 34(5), 34-37. https://doi.org/10.1002/pfi.4170340509

Steinglass, S. H. (1988). Section 1983 litigation in state courts. New York City: Clark Boardman.

Swanberg, S. P. (1992). Can a private association ever be libel under 42 U.S.C. $§ 1983$ for depriving an individual of fourteenth amendment due process rights after NCAA v. Tarkanian? Brigham Young University Education and Law Journal, 1, 131-142.

Van Wart, M., N., Cayer, J., \& Cook, S. (1993). Handbook of training and development for the public sector. San Francisco, CA: Jossey-Bass Publishers.

Walter, R. (1992). Public employers' potential liability for negligence in employment decisions. Public Administration Review, 52(5), 491-496. https://doi.org/10.2307/976809

Ward, G. (1988). High-risk training. N.Y.: Nichols Publishing.

Zinn, H. (2015). A Peoples History of the United States. N.Y.: Harper Collins Publishers.

\section{Copyright Disclaimer}

Copyright for this article is retained by the author(s), with first publication rights granted to the journal.

This is an open-access article distributed under the terms and conditions of the Creative Commons Attribution license (http://creativecommons.org/licenses/by/4.0/). 